\title{
Stigmatics, Politics and the Law
}

\author{
On Fake Stigmata and "Self-styled" Sanctity in Spain and France
}

\author{
Andrea Graus
}

The nineteenth and early twentieth centuries saw the establishment of constitutional monarchies and new political regimes during the formation of the modern nation-states. The conflicts between secular and Catholic authorities involved in this process had an impact on the manifestation of the allegedly supernatural. During such crises, stigmatics sometimes endorsed or, at least, indirectly supported, politico-religious movements with their visions and prophecies. However, in general, it was others, both advocates and opponents, who gave meaning to these mystical experiences, shaping them to symbolize particular hopes and anxieties. In these cases, the apparition of the holy wounds or an increase in the stigmatic's suffering were perceived as a response to situations such as the passing of secularization laws or attacks on the Vatican. The word "perceived" is key because, as mentioned, the symbolic meaning of stigmatics was generally an external attribution by another.

In previous chapters, we have seen how devotees of stigmatics deemed them "living saints," or how their suffering was perceived as productive in atoning for the sins of humanity. This attribution of meaning, however, could also be negative, condemning stigmatics as "self-styled saints" and "mystic tricksters" who were allegedly attempting to advance a political agenda with their "fake stigmata" and their alleged reputation of holiness. This chapter analyses this other side, showing how cases that could have merely remained within a narrative of popular devotion and Catholic mobilization were turned into stigmatic fraudsters and political symbols of various kinds.

Our focus will be nineteenth-century Spain and France, in specific moments of tension between the secular authorities and Catholicism, where two celebrity stigmatics of the era came to be perceived as "political dangers" to the modern State. The two stigmatics concerned were the Spanish Franciscan nun, Sor Patrocinio (religious name of María Josefa de los Dolores Quiroga y Cacopardo, 1811-1891), and the French peasant, Rosette Tamisier (1816-1899).

As we will see, the anticlerical liberals and republicans in power attacked their reputation for sanctity and the authenticity of their stigmata in an attempt to neutralize their effects in the public sphere. To achieve this, lawsuits 
were filed in each case and anticlerical campaigns were staged against them. The objective of the authorities was to transform these women into famous examples of "stigmatic fraudsters"; that is, in these cases, they were portrayed as someone trying to pass themselves off as a saint through the miracle of the stigmata, with the alleged goal to exploit the credulity of the people and gain power and fame. In both cases, the secular attacks were successful, with Sor Patrocinio and Rosette Tamisier both gaining a reputation as frauds in their own country as well as abroad. They were stereotyped to a point that their names continued to be evoked in the anticlerical press to discredit stigmata and similar examples of miraculous phenomena after them. This notion was thus opposed to the idea of a "true stigmatic" that, as seen in the previous chapter, was being constructed on the basis of promotional images of nineteenthcentury canonical stigmatics.

The cases of Sor Patrocinio and Rosette Tamisier may have functioned quite independently as particular examples of fraud in their respective countries; however, their stories were connected in public opinion across Europe after the French stigmatic was convicted for faking the holy wounds and other miracles in 1851 , just as had occurred to Sor Patrocinio in Spain in 1836. According to certain French figures such as the journalist and writer Wilfrid de Fonvielle, the secular repression and condemnation of Tamisier was inspired by "the memory of sister Patrocinio's adventures, another self-styled stigmatic, whom the Spanish magistrates themselves had come to be convinced of imposture and deceit." Thus, in looking at the French and Spanish cases together, we can identify analogous dynamics in combatting politically meaningful stigmatics in the public sphere and presenting their cases as fraud on the European level.

In analysing the political symbolism and public debunking of these stigmatics, we are dealing with their public personae. Studies in public personae, notably represented by scholars such as David Marshall, have focused on the contemporary era, with an emphasis on mass media and the online public self. $^{2}$ Although they were nineteenth-century stigmatics, Sor Patrocinio and Rosette Tamisier also had a kind of "mediatized identity"3 often linked to celebrities. Their fame and public personae were built up in the daily press and via vox populi testimonials, usually from important figures; for example, Sor Patrocinio received the backing of the Spanish royals, who considered her

1 Fonvielle, La physique des miracles (1872), 191. "Peut-être Rose Tamisier aurait-elle pu échapper à l'humiliation temporaire qu'elle dut accepter comme une épreuve d'en haut. / Mais ce qui la perdit sans doute aux yeux des juges de la cour d'Aix, ce fut le souvenir des aventures de la sœur Patrocinio, une autre stigmatisée prétendue, que les magistrats espagnols euxmêmes venaient de convaincre d'imposture et de supercherie."

2 Marshall, "Persona studies," 164-165; Marshall, Moore and Barbour, "Persona as method," 291.

3 Marshall, "Monitoring persona," 116. 


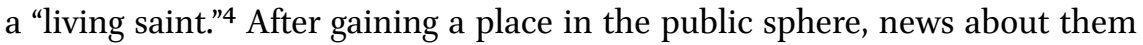
circulated in the national media and abroad. The reports of "miracles" and the trial of Rosette Tamisier were repeated in the French, Spanish, British, Italian, American and Dutch press and possibly elsewhere. ${ }^{5}$ The media attention attracted more advocates and opponents to the story, turning the discussion of their alleged sanctity and holy wounds into a public debate.

While for many stigmatics who came into conflict with secular authorities the sources are scarce and do not permit an in-depth analysis, in these cases we do find archival material, as well as some exceptional primary sources, including separate accounts of the lawsuits and anticlerical satirical poems and cartoons about them. ${ }^{6}$ The fact that some of the sources were published abroad shows the international interest in these stigmatics. When combined, this material gives us an impression of how these stigmatics ultimately became political symbols and famous examples of "feigned holiness" and "fake stigmata" in Europe, as opposed to how they no doubt wanted to be perceived. To examine how this occurred, we begin by discussing the relationship between stigmatics and political symbolism, offering a summary overview of nineteenth and early twentieth-century Europe. We then analyse how Sor Patrocinio and Rosette Tamisier came to be perceived as political symbols in the battles of the "two Spains" and "Frances." Finally, we show how their public reputation as stigmatic fraudsters and self-styled saints was constructed in the courtroom in their own countries and by the anticlerical press in Europe.

Stigmatics and Political Symbolism

Scholars such as David Blackbourn and William A. Christian have shown how apparitions, visions and other extraordinary phenomena become loaded with

4 Graus, "Wonder nuns," 572-577.

5 See, e.g., "Cours et tribunaux. Justice criminelle. Affaire Tamisier," Le Constitutionnel, September 7, 1851, 2-3; "Trial of Rose Tamisier, the miracle worker," London Daily News, September 8, 1851, 3; "Crónica religiosa," El Áncora, January 14, 1851, 219-220; "Rose Tamisier," Vaderlandsche Letteroefeningen 53 (1853), 425-428; "Miraculous picture in France," The American and Foreign Christian Union, 2 (1851), 105-106; "I miracoli di Rosetta Tamisier," Gazzetta del Popolo, September 15, 1851, 2-3.

6 As for the archival material, the diocesan dossier and other archival material concerning Rosette Tamisier can be found in: Archives Départementales de Vaucluse (ADV), Avignon, 2Mi732, 13J47. The cause of beatification of Sor Patrocinio can be consulted in the Archivo Diocesano de Toledo (ADT). Documents from politicians or the royal family concerning her can be found in the Archivo General de Palacio (AGP) and the Archivo Histórico Nacional (AHN), both in Madrid. 
political meaning during times of turmoil that menace Catholicism. ${ }^{7}$ Moments of crisis bring opportunities for change, and supernatural phenomena linked to such crises can influence the way a situation evolves. Just like the seers at Marian apparition sites, the Catholic vocation of several stigmatics in Europe coincided with episodes of violence and political upheaval. ${ }^{8}$ As a French journalist remarked ironically with regard to Sor Patrocinio in 1872: "it is not enough to have the stigmata, one must have them on time."9

Although the political and religious constraints that turned stigmatics into symbols are diverse and need to be properly contextualized for each case, we can identify some common denominators. As with modern apparitions and Catholic apocalyptic prophecies, there is a link between the alleged political oppression of Catholics and the perceived symbolic meaning of stigmatics. Their symbolism is often connected to some of the great perceived "enemies" of Catholicism, namely, anticlerical liberalism and republicanism in the nineteenth century, and communism in the twentieth century. ${ }^{10}$

As we will see in detail, the cases of Sor Patrocinio and Rosette Tamisier are exemplary of the Catholic struggle with liberals, republicans and the ambitions of the modern nation-state. In the same period, other "supernatural" manifestations, such as the apparitions of La Salette (France, 1846), were also reactionary and became the target of anticlerical movements. ${ }^{11}$ In the twentieth century, stigmatics such as the German Therese Neumann (1898-1962) and her Konnersreuth circle became a symbol of anti-communism, while in Italy the Venerable Edvige Carboni (1880-1952) offered herself up as a victim soul for the conversion of communists. ${ }^{12}$ The apparitions of Fatima (Portugal, 1917) are another well-known instance of this. ${ }^{13}$ The political symbolism of the stigmatics that we mention below also fit into these "paradigmatic" narratives concerning the perceived great adversaries of Catholicism.

The apparitions of Marpingen (Germany, 1876) cannot be understood without taking into consideration the context of the Kulturkampf, nor can those of Ezkioga (Spain, 1931) without referring to the Second Spanish Republic. See, respectively: Blackbourn, Marpingen, 36-42 and 113-120; Christian, Visionaries, 3-8.

8 Kane, "Stigmatic Cults," 109-114. See Chapter 1, Charting stigmatics.

9 Fonvielle, La physique des miracles, 192, "Ce n'est pas tout d'avoir des stigmates, il faut qu'on les ai à temps."

10 Blackbourn, Marpingen, 37; Christian, Visionaries, 8.

11 Lalouette, "La Salette," 119-120.

12 For Neumann, see O'Sullivan, Disruptive power, 106-107. For Carboni, see Peña, Eduviges Carboni, 14-16, 31-32. See also the biography of her in the Stigmatics online database and the appendix.

Barreto, "Rússia e Fátima," 500-503. 
While becoming a political symbol, the role that the stigmatic took up might be deemed active or passive, sometimes changing from one to the other. ${ }^{14}$ In a passive role, it was the suffering body of the stigmatic that seemed to speak for itself and no further meaning, through visions or prophecies, was needed to become a symbol. For example, the stigmatic Maria von Mörl (1812-1868) was called the Estatica for her absorbed state of contemplation and suffering, which was interpreted as a symbol of the conflict between the dual national and religious identities after the return of South Tyrol to Austrian rule. ${ }^{15}$ In Belgium, Louise Lateau (1850-1883) also spent part of her life in silent suffering, and her case was taken up in Germany during the Kulturkampf, in which she was seen as a victim soul comforting German Catholics. ${ }^{16}$

Apart from the political meaning given to a stigmatic's suffering, ${ }^{17}$ especially if it increased during a crisis that menaced Catholicism, the mere apparition of the wounds was sometimes deemed to be a sign of the difficulties faced by the Church. For example, in France, Madeleine Parsi (1884-1926) was stigmatized after her Benedictine convent was secularized, along with many other religious institutions, following a law of 1901. In Spain, the nun Lucila González (19081936) started reliving the Passion in the same month as the proclamation of the Second Republic, which was followed by a violent anticlerical wave and the burning of religious buildings by the communists. ${ }^{18}$ As in the cases mentioned above, bodily phenomenon occurring during a particularly challenging time was sufficient to ascribe a political meaning to the stigmatic.

The examples cited might give us the impression that stigmatics who became political symbols did not engage more directly in public. However, on many occasions we find that, in addition to bearing the wounds during difficult times, some stigmatics had visions or made prophecies about political outcomes in Europe. While, in theory, visions and prophecies are "divine revelations" and do not necessarily represent the stigmatics' wishes or opinions, such phenomena were nevertheless perceived or promoted as a form of public engagement on their part. In this vein, the stigmatics were deemed to endorse the causes about which they prophesized, and thus became "active" symbols of a political nature. ${ }^{19}$ Being almost exclusively women, their cases fit into a long tradition

\footnotetext{
14 Pahud de Mortanges, "Irre," 213-214. On the shift from one type to another, see: Van Osselaer, "Stigmata."

15 Gadaleta, "Rosmini," 168-170.

16 Lachapelle, "Between miracle and sickness," 87; Van Osselaer, "Stigmata," 598-6o2.

17 On suffering and stigmatics, see Chapter 3.

18 See, respectively, Canioni, L'Histoire extraordinaire, 23-29; Baumert, Beata Lucila González María de Jesús. Adoratriz.

19 On mysticism and public engagement, see Sheldrake, "Christian spirituality."
} 
of political visionary mysticism and womanhood within Catholicism..$^{20}$ The stigmatic, Catherine of Siena, to mention a well-studied example, participated in politics through her mystical experiences during the War of the Eight Saints $\left(1375^{-1378)}\right.$ between the papacy and the Florence coalition. ${ }^{21}$

With regard to nineteenth-century stigmatics, scholars such as Hilaire Multon have analysed the apocalyptic prophecies spread in Italy and France by Palma Matarrelli (1825-1888) and the stigmatics of the Third Republic, many of which we mentioned in Chapter 4. Their messages fuelled the ultramontane Catholic hope for a monarchic restoration to challenge anticlerical liberal and republican governments, thus favouring the return of the Ancien Régime and the triumph of the Holy See after the loss of temporal power. ${ }^{22}$ The prophetic function exercised by some stigmatics continued during the twentieth century, especially in the face of traumatic events such as the two World Wars, during which, as historians such as Owen Davies and Matthew Brower have shown, there was an increase in spiritual anxiety and a consequent rise in supernatural manifestations. ${ }^{23}$ By way of example, we can name the stigmatized "holy nuns" Elena Aiello (Italy, 1895-1961) and Ramona Llimargas (Spain, 1892-1940), who had visions regarding the destiny of the dictators Mussolini and Franco, respectively, and fuelled the Catholic fear of a "communist conquest." 24

Whether acting as "active" or "passive" symbols, the stigmatics' supporters, as well as their opponents, contributed to their political meaning, and this needs to be properly contextualized in each case, as will be done when considering the cases of Sor Patrocinio and Rosette Tamisier below. For the moment, it is

$20 \quad$ Kagan, Lucrecia's dreams, 4; Maître, Mystique et féminité, 296-297.

21 On this issue see, Luongo, The saintly politics, chapter 5 . The scholar Grace Jantzen has interpreted the case of Catherine of Siena and other female mystics as a form of empowerment within the Christian "patriarchy." Jantzen, Power, 216-223.

22 Kselman, Miracles, 130-140; Multon, "Prophétesses," 131-137; Sandoni, "Political mobilizations," 28-34. For Marie Bergadieu (alias Berguille) in particular, see Lachapelle, "Prophecies," 57-62. In the same period, in Belgium, Louise Lateau also made some apocalyptic prophecies, thus abandoning her silent role and becoming involved in the liberal and ultramontane Catholic conflict following the death of Pius IX in 1878, Van Osselaer, "Stigmata," 604.

23 Brower, Unruly spirits, 93; Davies, A supernatural War, 1 and especially Chapter 3 for spiritualist phenomena and the First World War.

24 Aiello prophesized Mussolini's fall, while during the Spanish Civil War, Llimargas transmitted the result of the battles to Franco before they had been fought. The latter was allegedly done through bilocation. See, respectively, París García, El tiempo, 231; Fernández Rodríguez, Ramona María del Remedio Llimargas Soler, 53-57. In Germany, some accounts suggest that Therese Neumann intended to collaborate with the Third Reich, and rumours suggest that the Nazis feared her "supernatural power," but there is no documentary evidence. O'Sullivan, “Disruptive potential," 193. 
also worth noting that the political symbolism of stigmatics may continue after their death, when they can no longer play a personal role. For example, Father Yannik Bonnet, a devotee of the French stigmatic Marthe Robin (1902-1981), spoke about a prophecy he allegedly received from Robin when he visited her at home in the 1970s, and which concerned a "French renewal." In recent years, Father Bonnet has promoted this prophecy in his blog and at public conferences to stimulate the Catholic hope that France would become "the daughter of the Church" again. This hope became associated with a potential triumph of Marine Le Pen during the 2017 presidential elections, when Robin's prophecy was interpreted in Catholic internet forums as a sign that the extreme-right Front National party would win. The postulators of Robin's cause of beatification publicly denounced Father Bonnet, who died in 2018 and whose blog has now been removed. ${ }^{25}$

As this brief overview shows, the political symbolism of stigmatics took form within particular contexts and could be negative or positive, or more frequently, both; for example, the stigmatics of the French Third Republic were idealized by legitimists and ultramontanes, who found comfort in their alleged expiation of the "sins of France," but they also attracted the hatred of the republicans, as had previously occurred in the case of Rosette Tamisier. ${ }^{26}$ In the following section, we examine the political symbolism ascribed to this stigmatic, as well as to Sor Patrocinio, within the "two Frances" and "Spains." As we will see, in becoming celebrity stigmatics and "active" symbols in the public sphere, they became a political threat to the modern State that, according to the liberals and republicans in power, needed to be neutralized.

\section{Sor Patrocinio, Rosette Tamisier and the "Two Spains/Frances"}

Although Sor Patrocinio was a religious and not a lay woman, her case fits the typical stigmatic type of the era with regard to her visibility, the importance of the holy wounds for her profile, and how people became increasingly interested in her. Her stigmatization occurred in 1829 after joining a Franciscan

\footnotetext{
25 The blog was: www.yannikbonnet.com (last accessed 16 February 2019). A lecture he gave on this subject: https://www.youtube.com/watch?v=A4piXouhYbM (accessed 16 February 2019). On this subject, see also an interview of Bernard Peyrous, until 2017, the postulator of Robin's cause of beatification: https://www.martherobin.com/sa-vie/ un-rayonnement-immense/des-propheties-de-marthe-robin-sur-la-france/ (accessed 20 November 2018).

26 Sandoni, "Political mobilizations," 20-24.
} 
convent in Madrid. ${ }^{27}$ The convent was said to be the object of generous donations from the aristocracy and the royals, who came to the monastery to meet the "holy nun." In this vein, the convent also became a kind of "domestic setting," where visitors could obtain "relics" or grace from the stigmatic. ${ }^{28}$ Sor Patrocinio soon became popularly known as "the nun with the wounds" ("la monja de las llagas"). ${ }^{29}$ This epithet was used in Spain and abroad, in countries such as France and the United Kingdom, where she was also referred to as "the bleeding nun" or "the nun of the Stigmata." 30

Twenty years later, Rosette Tamisier, a peasant woman from Provence, also became an internationally renowned stigmatic. Her chest was allegedly covered with figurative wounds representing a heart or a cross. The house in which she lived was given the name, "the Saint's Inn" ("L'Auberge de la Sainte"), and bloody linen with the figurative stigmata started to circulate. ${ }^{31}$ Another "miracle" that contributed to her fame was an alleged painting of the pietà that bled before her in the chapel of Saint Saturnin-lès-Apt. The phenomenon attracted hundreds of people from around France and abroad, who had the opportunity to meet the stigmatic. ${ }^{32}$

While other typical stigmatics in France would "succeed" Tamisier, ${ }^{33}$ Sor Patrocinio would remain the most remembered stigmatic in Spain. In the press, some stigmatics (religious and lay) who appeared after her were deemed the "new Sor Patrocinio."34 Especially telling was the case of Therese Neumann a century later, whom the Spanish journals referred to as "the German Sor Patrocinio." 35

Unlike other celebrity stigmatics, however, the international reputations of both Sor Patrocinio and Rosette Tamisier were almost exclusively as frauds.

27 As well as stigmata, Sor Patrocinio experienced other extraordinary phenomena, from diabolical attacks to levitation, to miraculous healing, apparitions and the gift of prophecy.

28 On this issue see Chapter 4.

29 Most biographies of Sor Patrocinio include "the nun with the wounds" in their titles, since she was very well known by this epithet. The most popular biography is by Benjamín Jarnés, entitled Sor Patrocinio. La monja de las llagas (1929).

30 See, among others, Manning, Spanish pictures drawn with pen and pencil (1870), 83; "Foreign intelligence," Bury and Norwich Post, October 31, 1849, 1; "Foreign news," Hertford Mercury and Reformer, November 3, 1849, 1.

31 Anonymous, Procès de Rose Tamisier (Miracles de Saint-Saturnin) (1851), 3.

32 See, e.g., "Trial of Rose Tamisier, the miracle worker," London Daily News, September 8, 1851, 3; "Crónica religiosa," El Áncora, January 14, 1851, 219-220. Handkerchiefs imprinted with blood from the holy wounds have been preserved in the archives, 2Mi732, ADV.

33 See the stigmatics of the early Third Republic analysed in Chapter 4.

34 "Manojo de flores místicas," El Motín, 2.20 (1882):1-2.

35 See, e.g., "Otra vez Teresa Neumann, la Sor Patrocinio alemana," El Heraldo de Madrid, October 21, 1932, 1 . 
It is difficult to find other stigmatics who became as renowned at the European level in public opinion. This international reputation was the consequence, on the one hand, of their respective trials - which we will examine below - and, on the other hand, of the fact that the stigmata and other miracles took place in the midst of political upheavals.

In Spain, Sor Patrocinio's stigmatization coincided with the death of the absolutist king Fernando VII and the First Carlist War (1833-1840). In this civil war, the liberal supporters of Isabel II, daughter of the king, were challenged by the Carlists, who supported Don Carlos, brother of the king, who was favourable to the ancien régime, and who took Sor Patrocinio under their wing. Rosette Tamisier bore the holy wounds at the end of the short-lived French Second Republic (1848-1851), which saw great tensions between the Bonapartists, who held power, and the Orleanists, who had been dethroned in the revolution of 1848. In this case, the stigmatic received the support of the ultramontanes who fought against the Republic.

As we can see, their stigmatization occurred during moments of change in the national regimes, and within the wider liberal and republican revolutionary waves of the 183 os and of 1848 in Europe. ${ }^{36}$ In this context, their stigmatization was not perceived to be politically neutral, and the stigmatics themselves contributed to the growth of their symbolic meaning. Unlike the "passive" stigmatics, whose bodies seemed to speak for themselves, these women were active in stimulating the hopes of their supporters through alleged prophecies and further miracles. For example, Sor Patrocinio allegedly predicted the rise of Don Carlos, the absolutist pretender to the throne of Spain, while Rosette Tamisier's miracle of the bleeding painting became a form of Catholic propaganda in the ultramontane press. ${ }^{37}$

While Sor Patrocinio became the enemy of the liberals and came to represent the clash between liberalism and absolutism in Spain,, ${ }^{38}$ Tamisier's case is part of what James McMillan called a "longer-running guerre des deux Frances." ${ }^{39}$ The appellative of the "two Frances" was widely used at the time to differentiate between the liberal republican and the clerical factions. In 1905, the historian Paul Seippel offered the following definition: "What are these

36 Thus, although they took on symbolic meaning during particular national crises, these crises were part of larger revolutionary waves, in which other stigmatics acquired political meanings in their own homelands - for example, the stigmatics of the South Tyrol. Priesching, Maria von Mörl (1812-1868).

37 Graus, "Wonder nuns," 573; Marx, Le péché de la France, 283.

38 See, e.g., Jarnés, Sor Patrocinio, 101; Dom Liber (pseudonym of Charles Potvin), Le faux miracle du Saint Sacrement (Bruxelles: Adrian Campan, 1874), LVII.

McMillan, "Priest hits girl," 77 . 
two Frances? Everyone can easily distinguish them: France of the Church and France of the Revolution, France of the Syllabus and France of the Declaration of Human Rights." 40 The scholar Christopher Clark employed the same concept to write about the "two Spains" which were battling in Sor Patrocinio's case, the "two Italys" or even the "two Romes": that of the Vatican, and the other of the Italian kingdom. ${ }^{41}$

In becoming celebrity stigmatics, Sor Patrocinio and Rosette Tamisier also became icons of "the other" Spain or France: those advocating an absolutist monarchy and the temporal power of the Vatican, and opposing the secular and "progressive" ideals of the modern State taking shape in their country. The liberals and republicans in power responded to this and spoke about the danger of allowing the miraculous to influence the masses and State affairs. To this end, they denounced the alleged exploitation of the supernatural on the part of the stigmatics and their supporters. For example, Spanish liberals accused the Carlists and Sor Patrocinio of hindering liberal reforms and the establishment of a constitutional monarchy. ${ }^{42}$ In France, the republicans argued that Rosette Tamisier collaborated with "religious jugglers" or "pious mystifiers" such as Louis Veuillot, the famous director of the ultramontane newspaper, L'Univers, who allegedly used the supernatural "to exploit the credulity" of the people. ${ }^{43}$

Furthermore, the political enemies of the stigmatics attempted to link their story with a denigrating idea of religious belief as a form of "superstition" or "fanaticism" - a term frequently used to describe Sor Patrocinio's case. ${ }^{44}$ They

40 Seippel, Les deux Frances et leurs origines historiques (Paris: Félix Alcan, 1905), XII: "Quelles sont donc ces deux Frances? Chacun les distingue aisément: La France de l'Église et la France de la Révolution, la France du Syllabus et la France de la Déclaration des Droits de l'homme."

41 Clark, "The new Catholicism," 42.

42 See, e.g., Dos Amigos Filósofos (pseudonym), Biografía de Sor Patrocinio, o sea la célebre monja de las llagas (Madrid: Imp. de los Sres. Rojas, 1868), 63-64 and 8o.

43 Émile de la Bédollière, "Partie politique," Le Siècle, May 9, 1857, 1. On the role of Veuillot and L'Univers in the French context, see Hérisson, "Louis Veuillot." In 1871, another famous stigmatic, the Italian, Palma Matarrelli, was said to be "in spiritual contact" with Veuillot while making Royalist prophecies about the future of France. About Matarrelli, Veuillot and Imbert-Gourbeyre see, letter from Louis Veuillot to Antoine Imbert-Gourbeyre, 10 June 1872 , Correspondance et papiers de Louis Veuillot ( ${ }^{\text {re }}$ série), NAF 24222, fol. 300-301, Bibliothèque Nationale de France (Richelieu); Imbert-Gourbeyre, Les Stigmatisées, $I I$, 3 о.

44 See, e. g., Garrido, L’Espagne contemporaine (1862), 112; Jarnés, Sor Patrocinio, 101; Liber, Le faux miracle, LXVIII. 
countered these notions with "modern" ideals of science and progress, which had a deep influence in nineteenth-century society. ${ }^{45}$ For example, French republicans such as Émile de la Bédollière and Louis Jourdan, self-declared enemies of Louis Veuillot, compared the discoveries of science with Tamisier's miracles, which, according to Jourdan, contributed "to maintaining the coarsest superstitions among the ignorant masses." 46

The arguments of religious exploitation and superstition were also recurrent in other "culture wars" of the era, where the stigmata, as well as other supernatural manifestations, acquired politically symbolic significance. For example, the liberals in Belgium and Germany attacked the Catholic priest and journalist Paul Majunke for allegedly exploiting Louise Lateau's image as a victim soul to comfort German Catholics during the Kulturkampf. ${ }^{47}$ In the case of apparitions, David Blackbourn argued that for nineteenth-century nation-state builders and their "modern" supporters, Marian apparitions were "instances of ignorance and superstition" that needed to be combatted. ${ }^{48}$ Scholars such as Jacqueline Lalouette have shown how these discourses worked in cases such as La Salette (1846). ${ }^{49}$

Thus, from the point of view of the liberal and republican authorities involved in the building of modern France and Spain, there was a political need to repress Sor Patrocinio and Rosette Tamisier. Given the celebrity they had already achieved as stigmatics and potential saints-to-be, there was a need to attack their public personae. This was done using two powerful weapons: the law, where accusations of fraud and religious exploitation were presented in a formal manner; and the media, including the anticlerical press, the great ally of republicanism and progressive liberalism in Europe. We will later look at how the anticlerical press mocked the stigmatics in caricatures and satirical texts to denigrate their public personae. In the following, we examine how their public image as fraudsters began to be constructed in the secular courts of their respective countries, subsequently becoming internationally renowned.

45 This contrast between "rational" or "scientific" knowledge and "superstitious" belief would be later taken up in the sociological thesis of disenchantment, contested, among others, by the scholar Egil Asprem. See Asprem, The problem of disenchantment, 4-8.

46 Article by Louis Jourdan in Journal des débats, 1857, cited in Veuillot, Mélanges religieux, vol. III (186o), 69-71, "entretenir parmi les masses ignorantes les plus grossières superstitions." On Émile de la Bédollière, see Jean-Vaudin, Gazetiers et gazettes (186o), 212-214.

47 Van Osselaer, "Stigmata," 6o2.

48 Blackbourn, Marpingen, 41.

49 Lalouette, "La Salette," 129-131. 
Initiating a lawsuit in which the stigmata were involved was exceptional, usually reserved for those cases with a strong politico-symbolic meaning. Our research on hundreds of stigmatics has revealed a little more than a dozen instances where a stigmatic was tried or, at least, faced arrest and brief imprisonment. We must note, however, that the lawsuits or arrests were usually related to ordinary offences that did not concern their mysticism, or addressed other allegedly fraudulent aspects of their religious experience and not the stigmata. ${ }^{50}$ For example, in 1926, in Corsica, the above-mentioned Madeleine Parsi was accused of calumny for using perfume to fake the sweet odour that saints emanate and defraud people using her pretence to holiness. ${ }^{51}$

The lawsuits against Sor Patrocinio and Rosette Tamisier were two of the very few cases in which stigmata were addressed in the secular courts. ${ }^{52}$ Another known case involved the Alsatian, Catherine Filljung (1848-1915), a political prophet and stigmatic who became a symbol opposing the German annexation of Alsace-Lorraine (1871). She was tried in Germany in 1891 for allegedly faking ecstasy and the holy wounds. ${ }^{53}$ Despite the echo that Filljung's case found in France and Germany, the most internationally renowned stigmatic trials were those of Sor Patrocinio and Rosette Tamisier. As with Filljung, the lawsuits demonstrate their political meaning, and that the stigmata addressed in the courtroom - were relevant to their public personae.

$5^{\circ}$ For a more general approach to how different mystical phenomena were translated into criminal charges in the nineteenth-century secular courts, including the three cases mentioned above, see Graus, "Mysticism."

51 Canioni, L'Histoire extraordinaire d'Hélène Parsi. Another example is the French stigmatic who was tried in France and Italy, the antipope Clément XV (Michel Collin, 1905-1974), but he was accused of being a swindle in his "Petit Vatican" in Clémery, and for insulting Pope Paul vi. See Delestre, Clément $X V$, 92. For information on this and other cases, see the keyword "lawsuit" in the Stigmatics database.

$5^{2}$ In the 188 os, the German woman, Sabine Schäfer, was imprisoned for ten weeks in Baden after a bottle of blood and an instrument that could produce the wounds was found under her bed. Another interesting trial is that of Bertha Mrazek (189o-1967, a.k.a. Georges Marasco), a Belgian stigmatic and miraculée who was tried in 1924 for obtaining money under false pretences and was sent to an asylum. In this case, however, it is not clear if the holy wounds were addressed in the trial, as no records survive. See biographies in the Stigmatics database and the appendix; as well as Thurston, Surprising mystics, 210-213; and Van Osselaer, "The many lives of Bertha, Georges and Jean."

53 See Catherine Filljung, VI-Q-62bis, Archives de la Province Dominicaine de France (APDF), Bibliothèque du Saulchoir. For a biography favourable to Catherine Filljung, see Ebel, Sour Catherine (1929). For an unfavourable one, see Pelt, La vérité sur Catherine Filljung (1934). 
The lawsuits confirmed their political symbolism from the moment they were initiated. In the Spanish case, the liberal governor of Madrid decided to initiate the lawsuit, while in the French case, it was the public prosecutor (procureur de la République) of Apt. In other words, they were both representatives of the governing establishment that the stigmatics supposedly challenged. To initiate the lawsuit, both men alleged that the stigmatic had caused the political turmoil in their country. The French public prosecutor called the outcome of Tamisier's stigmata and other miracles "too factious (factieux)" - that is, seditious or inciting acts against the established order - "to not have justice deal with it in the end. ${ }^{54}$ Sor Patrocinio was directly accused of attempting to subvert the State with her alleged prophecies and simulation of the holy wounds. According to the accusation, these "impostures" could affect "the tranquillity of the State and the Throne."55 In each case, the lawsuits followed the political narrative that, with their pretence to the supernatural, the stigmatics acted against the modern State.

The legal strategy of the public prosecutors backed liberal and republican intentions to present these cases as a form of religious exploitation, especially pointing to the issues of sanctity and the stigmata. In Spain, Sor Patrocinio and her religious community were accused of "trafficking" in the miracle of the stigmata. According to the prosecutor, the fraud was staged with the aim to "have a saint" in their convent and obtain donations from the aristocracy and the royals, who asked for "bloody relics" from the nun. ${ }^{56}$ Similar arguments were advanced in France, where Rosette Tamisier was said to "pose as a saint" in order to receive money, jewels and clothes. To raise doubt about the stigmata, the public prosecutor said the wounds only appeared after Tamisier was visited by a member of a Catholic sect whose leader, the prophet Pierre-Michel Eugène Vintras, had been incarcerated a few years earlier for fraud. ${ }^{57}$ The defence attorneys attempted to prove the women's innocence by arguing that they had been victims rather than co-conspirators in a religious plot. ${ }^{58}$

54 Letter of the public prosecutor of Apt, 1 January 1851, 2Mi732, ADV: "un trop factieux résultat, pour que la justice n'ait pas dû, à la fin, s'en préoccuper."

55 Anonymous, Causa formada (1837), inside cover page; Jarnés, Sor Patrocinio, 200.

56 Anonymous, Extracto de la causa seguida a Sor Patrocinio (1849), 8 o.

57 Anonymous, Procès de Rose Tamisier (1851), 20. See also letter of the public prosecutor of Apt, 1 January 1851, 2Mi732, ADV. On Vintras, see Maurice Garçon, Vintras, hérésiarque et prophète (Paris: Emile Nourry, 1928); Robert Ziegler, Satanism, magic and mysticism in finde-siècle France (New York: Palgrave Macmillan, 2012), 116-181.

$5^{8}$ Anonymous, Extracto de la causa seguida a Sor Patrocinio, 85; Anonymous, Procès de Rose Tamisier, 19 . 
To prove that the holy wounds were premeditated, and thus that the fraud was intentional, the public prosecutors relied on "expert testimony"; that is, scientists, usually physicians, were asked to analyse the facts based on their expertise. During the nineteenth century, expert testimony was only required during trials involving crimes such as murder, and it was unusual to use it in minor crimes such as fraud. ${ }^{59}$ In the cases examined, therefore, calling for expert testimony was no doubt done to reinforce the belief in science and progress that permeated modernity. For the liberals and republicans in France and Spain this would further assist their representation of the stigmata and other miracles as a form of superstition. Two surgeons rejected the supernatural as an explanation of Sor Patrocinio's wounds and two other physicians argued that Tamisier suffered from frequent and abundant menstruations, an argument frequently advanced to debunk the stigmata. ${ }^{60}$ Expert testimony was also called upon in Germany to examine the wounds of the above-mentioned Catherine Filljung - who was deemed hysterical - which suggests it was perhaps a more common legal strategy in cases of fraud involving stigmatics. ${ }^{61}$

Ultimately, the sentences condemned the defendants to a combined total of 21 months in prison as well as a fine for Tamisier and relocation to a convent far from the Royal Palace for Sor Patrocinio. ${ }^{62}$ After their condemnation, the two women came to represent the model of the "stigmatic fraudster"; of a

59 Eigen, "I answer as a physician," 167; Watson, "Medical and chemical expertise," 375-378.

6o A report on the expert testimony in Sor Patrocinio's case appeared in the press, "Medicina legal," Boletín de medicina, cirugía y farmacia, 3 (1836), 43. For the report on Tamisier, see Maurice Garçon, Rosette Tamisier ou la miraculeuse aventure (Paris: L'Artisan du livre, 1929), 78-79. In addition, in the case of Tamisier, a pharmacist debunked the miracle of the "bleeding painting" using a leech. See his report for the judge in Garçon, Rosette Tamisier, 89. For the argument of menstruation and the stigmata, see e.g., Alfred Maury, "Les mystiques extatiques et les stigmatisés," Annales médico-psychologiques, 1.2 (1855): 181-232, esp. 215 .

61 For a brief analysis of the role of expert testimony in Filljung's lawsuit, see Graus, "Mysticism," 34. The Belgian stigmatic Bertha Mrazek, mentioned above, was also deemed an hysteric and sent to an asylum after a trial in 1924. See Van Osselaer, "The many lives of Bertha, Georges and Jean."

62 Anonymous, Extracto de la causa seguida a Sor Patrocinio, 93-97; Anonymous, Procès de Rose Tamisier, 22. In the case of Tamisier, the sentence was initially six months, but she had to stay in prison longer because she could not pay the fine (16 francs). She spent almost two years in jail if we take into consideration her pre-trial detention. There were also several legal discussions concerning which article of the law was more appropriate to judge the facts concerning the "bleeding painting." Once the court of Carpentras judged the case was suitable for the assizes in Nîmes, they declared that the actions should fall under article 262, which condemns "anyone who, by word or action, shows contempt for the objects of a cult” (13J47, ADV); Garçon, Rosette Tamisier, 96-10o. 
woman simulating the holy wounds and other miracles to pass themselves off as a saint and obtain lucrative gifts, fame and power. Although Sor Patrocinio continued to nourish a cult within the Spanish royals, public opinion on her case became linked to the ideas of "fake stigmata" and "self-styled sanctity" that have survived her. ${ }^{63}$ In the case of Tamisier, the conviction destroyed her cult completely. ${ }^{64}$

From start to end, the lawsuits were an event of public interest. In line with the aim of the secular authorities to debunk the defendant in the public sphere, the hearings were open to the public, where the testimony of the experts, the pre-trial investigation and various declarations were presented. ${ }^{65} \mathrm{In}$ the case of Tamisier, crowds of people were reported to have waited outside the court each morning. To ensure a seat, the members of the public had to obtain "admission tickets" from the president of the court, which rapidly ran out. Although the information is scarce, it appears that the courtroom was completely packed. ${ }^{66}$ In the case of Sor Patrocinio, we do not know whether there was an admission policy or who was in the court, but apparently the hearing was relocated to a larger room to "better accommodate the public," 67 which also suggests that there were too many attendees.

Newspapers representing the government reported on the legal proceedings in support of the State's public discrediting of the stigmatics, including news on the pre-trial investigation and transcriptions of the declarations. In Spain, the Ministry of Justice distributed minutes of the different interrogations to supportive journals, such as the liberal-progressive El Eco del comercio, as well as the testimonies of the experts, in what came to be known as "the

63 Graus, "Wonder nuns," 572-577. On the relationship between Sor Patrocinio and the royals see, "Apuntes sobre sor Patrocinio," Reinados, Alfonso XII, 25017, exp. 17, AG P.

64 Garçon, Rosette Tamisier, 100-101.

65 In Tamisier's case, the hearings lasted four consecutive days, in which they interrogated the witnesses, the experts and the defendant, while for Sor Patrocinio, there was only one hearing, in which the declarations were presented and the attorneys made their concluding remarks. Being a cloistered nun, Sor Patrocinio and her religious community (the witnesses) were given the privilege of testifying in private in their convent, or in one of the two houses in which Sor Patrocinio was under domiciliary arrest. See, respectively, Jean-François André, Affaire Rosette Tamisier, précédée d'une notice sur Pierre-Michel Vintras et sa secte (Carpentras: Impr. L. Devillario, 1851), 25; Voltes, Sor Patrocinio, 89-91.

66 A group of women were placed in the jury's tribune and the prisoner's dock was also full. "Cours et tribunaux. Justice criminelle. Affaire Tamisier," Le Constitutionnel, September 7 , 1851, 2-3; "Tribunal correctionnel de Carpentras. Affaire Rosette Tamisier," Journal des débats politiques et littéraires, September 7, 1851, 3-4.

67 "Juzgados de primera instancia," Diario de Madrid, November 21, 1836, 1, "para mayor comodidad del público." 
famous lawsuit." 68 In France, the hearings were transcribed in Bonapartist newspapers that were critical of ultramontanism and the Church, such as Le Constitutionnel, one of the main journals of the Second Republic and later the Empire. ${ }^{69}$ A few months after each trial, booklet editions of the lawsuit texts appeared, including the testimonies, some of which were reprinted years after and in several editions. ${ }^{70}$ These were extraordinary publications that again show the stigmatics' celebrity and the public interest in their trials. ${ }^{71}$

The news of the lawsuits also reached other European countries, where liberal journals reported on the trials based on the chronicles appearing in the foreign press, thus contributing to the public debunking of the stigmatics abroad. For example, the French press described Sor Patrocinio as a "fanatic" and the "pythoness of the Carlists," while Rosette Tamisier was derided in British and Belgian journals, which coined phrases such as the "Miraclising spinster" and "heroine of a pretentious illuminism (illuminisme)." ${ }^{2}$ Thus, the attacks of the liberal press abroad supported those in the stigmatics' countries, in line with the "cross-border affinities" in newspaper journalism that Christopher Clark and Wolfram Kaiser identified in the wider secular-Catholic conflicts of the nineteenth century. ${ }^{73}$

68 See, e.g., "Causa célebre de Sor Patrocinio," El Nacional, June 18, 1836, 574. Minutes of the interrogations published in the press can be found in, for example, "Noticias oficiales," Eco del comercio, January 27, 1836, 5; "Ministerio de Gracia y Justicia," Revista Española, January $28,1836,2-3$.

69 See, e.g., "Cours et tribunaux. Justice criminelle. Affaire Tamisier," Le Constitutionnel, September $7,1851,3$.

70 Anonymous, Causa formada contra doña María de los Dolores Quiroga (1837); Anonymous, Procès de Rose Tamisier (1851); André, Affaire Rose Tamisier (1851). A new publication on Sor Patrocinio's lawsuit took place in 1849 (two reprints) and in 1864, when she was involved in further governmental affairs: Anonymous, Extracto de la causa seguida a Sor Patrocinio (1849). See, Voltes, Sor Patrocinio, 83.

71 In the Spanish press, the publication was deemed "very interesting" owing to the "public attention" Sor Patrocinio received. "Anuncio. Causa de Sor Patrocinio," El Español, February 18, 1837, 1 .

72 See, respectively, "fanatisée," "pythonisse des carlistes," in “Intérieur," Le Moniteur Universel, November 25, 1835, 1; "Miraclising spinster," Morning Advertiser, 8 September 1851, 3; "Cette hérö̈ne d'un illuminisme prétentieux," in "On lit," Le Messager de Gand, December 24, 1852, 3. See other news on the trials in e.g. "Trial of Rose Tamisier, the miracle worker," London Daily News, September 8, 1851, 3; "Sham miracles," Globe, September 9, 1851, 4; "Chronique judiciaire," Journal de Bruxelles, September 9, 1851, 3; "Rosa Tamisier detta la Santa," Gazzetta dei Tribunali, 1.74 (1851), 305-306.

73 Clark and Kaiser, "The European culture wars," 4-5. See also their respective chapters on New Catholicism and anticlerical media in Culture wars. 
Years after their conviction, the image of Sor Patrocinio and Rosette Tamisier as fraudsters would continue to be evoked throughout Europe by many different publications and authors. "Who was Sor Patrocinio?," asked an English poet and travel writer in 1868: "an intriguing impostor, once condemned by the public tribunal for having pretended to the miraculous possession of the Stigmata" $;{ }^{74}$ and also, more harshly: "a woman stained with false stigmata and armed with the fanaticism of the masses," 75 wrote a Belgian freethinker in 1874 . In a similar vein, the British evangelical press described Tamisier as "an impostor who so successfully mystified the world, and acquired by her miracles a sort of European celebrity."76

Judging from the image that came to represent these stigmatics after their trials, we can conclude that the Spanish and French secular authorities won the battle over public opinion. It would be misleading, however, to affirm that it was only the lawsuit that contributed to the stigmatics' reputations as fraudsters. As we will see below, from the moment the stigmatics became the target of the secular authorities, they featured in anticlerical press campaigns at home and abroad. In the following, we examine how these campaigns were designed to fulfil two aims: firstly, to present their cases as instances of fake stigmata and the pretence of holiness, thus backing the discourse of the French and Spanish secular authorities; and, secondly, to denounce the stigmatics' political symbolism and attack - by means of mocking them - the political enemies of anticlerical liberals and republicans.

\section{$4 \quad$ Fake Stigmata and Self-styled Sanctity in the Anticlerical Press}

Just as stigmatics had been idealized to reflect Catholic hopes in particular contexts, so they were demystified in the anticlerical press in Europe. Examining the cartoons and satirical texts ridiculing stigmatics gives us an idea of how anticlerical activists used these religious celebrities to advance their own agendas. Unlike the construction of stigmatics as "living saints," which usually implied a form of interaction with the devotees, their construction as

74 Betham-Edwards, Through Spain to the Sahara (1868), 157. Here and below, other examples could have been cited.

75 Dom Liber, pseudonym of the Belgian philosopher and freethinker Charles Potvin, gave a full chronicle of Sor Patrocinio's imposture in 1874, including a partial translation of the lawsuit text. See Liber, Le faux miracle, LVII-LXVIII. "Souillées des faux stigmates et armée du fanatisme des masses," (p. LXVIII). 
fraudsters in the anticlerical press was passive, meaning that stigmatics had no real involvement in the process. Nevertheless, the attacks were not completely to their detriment, insofar as "no publicity is bad publicity." In other words, mocking the stigmatics had the advantage of spreading their fame beyond the Catholic milieu.

Although religion had been a topic of mockery since early Christianity, it was not until the $185 \mathrm{os}$, with the reduction in printing costs and the revolutions of 1848 that anticlerical journals became a mass medium that could attack religion throughout Europe. The anticlerical press grew exponentially after events such as the Glorious Revolution in Spain, the Paris Commune and the Kulturkampf. ${ }^{77}$ With their distinctive transnational aims, the anticlerical press in Europe served to discredit religious figures internationally. This included important figures such as Pope Pius IX, as well as ultramontane activists and clergymen, and to a lesser extent, mystic figures. ${ }^{78}$ The mocking of Sor Patrocinio and Rosette Tamisier is a smaller, yet interesting, example of how this worked for stigmatics.

As Wolfram Kaiser has shown, anticlerical media frequently repeated the same motifs in their attacks. ${ }^{79}$ This also appears to be the case in the caricatures and satirical texts about stigmatics, which especially relied on notions of "feigned holiness" and "fake stigmata." For example, a famous anticlerical sonnet in Spain described the "hypocrite Sister" who produced the wounds using some kind of poison in an attempt to control the Throne, ${ }^{80}$ and in France, a small satirical press biography of Sor Patrocinio said she had declared herself stigmatized "to pass herself off as holy," and to manipulate the royals, and that this was "the beginning of her glory" ${ }^{\text {"1 }}$ As another amusing example of how

77 In antiquity, graffiti depicted Christians as donkeys, and in the early modern era there were drawings mocking the Protestant Reformation. The figure of God, it seems, was not a target until the end of the eighteenth century, Boespflug, "Brève histoire," 86-94; Doizy, "De la caricature anticléricale," 63-66.

78 On anticlerical caricature in France, in particular, see Dixmier, Lalouette and Pasamonik, La République.

79 Kaiser, "Clericalism," 70-73.

8o The satirical sonnet (copla) is as follows: "I fear that the sceptre will become a crosier [...] / I venerate God, I venerate the tabernacle; / but not a hypocrite Sister who with emetic tartar, / mimics the [holy] wounds [...] / If this cynical farce continues, all masks will fall / and all Spain will burn like a match." It is attributed to Manuel Bretón de los Herreros (1796-1873). Cited in Dos Amigos Filósofos, Biografía de Sor Patrocinio, 143.

81 The Bonapartist journal Le Gaulois published a drawing that portrayed Sor Patrocinio next to kings and other important figures of the 1868 Spanish revolution. They described her as follows: "she ate ONE OUNCE of bread per day! It was the beginning of her glory. To pass herself off as holy, she declared herself stigmatized and pretended that the wounds on 
the anticlerical press mocked these cases on a European level, it is worth citing the first strophe of a song that appeared in the London-based satirical journal Punch in 1851, the year of Rosette Tamisier's lawsuit, in which the topics of selfstyled sanctity and fake stigmata reappear.
Oh! my Saint is like the French girl, Rose,
Tamisier by surname, and leads me gently by the nose, with wonders just the same.
A heart, tattoo'd upon her breast, stains handkerchiefs and clothes; of course through miracle impress, as by the French girl, Rose. ${ }^{82}$

Attacking the two features of stigmata and sanctity, and pointing especially to the pretence of the holy wounds as an attempt to obtain a reputation for holiness, thus became a repeated motif in the mocking of Sor Patrocinio and Rosette Tamisier, both at home and abroad. As seen above, this motif was also discussed within the secular courts and the media reporting on the lawsuits. Once again, this shows the importance of these two features for these stigmatics' public personae, as well as the need, in the eyes of the anticlerical press and the secular authorities, to debunk them.

Apart from contributing to the stigmatics' reputation as fraudsters, the anticlerical press used the stigmatics' political symbolism in the war of the two Frances and two Spains to attack their political enemies. In her homeland, the mocking of Rosette Tamisier served to combat liberal Catholics and especially the ultramontanes. Satirical texts and anticlerical caricatures of her frequently included her political supporters, and a special favourite was the ultramontane, Louis Veuillot, the director of L'Univers. ${ }^{83}$ As evidence of her celebrity, Tamisier had the "privilege" of being caricaturized by Honoré Daumier, probably the most internationally renowned French caricaturist, who depicted

her hands, feet and side bled every Friday," L. Estor, “La révolution espagnole," Le Gaulois, October 17, 1868, 1 (emphasis in the original).

82 "The French girl Rose. A song of a modern saint," Punch 21 (1851), 125.

83 Several satirical texts about Rosette Tamisier and her supporters appeared in Le Charivari in the year of her trial. See "Le martyre de Sainte Rosette Tamisier," February 23, 2; "M. [Alfred] de Falloux et Rosette Tamisier," August 29, 1851, 2; "Nouveaux miracles dans le Vaucluse," September 6, 1851, 2. 
"Saint" Rosette Tamisier as a witch working one of her "miracles" on a fool-like Veuillot (Figure 6.1). ${ }^{84}$

Another small cartoon in Le Journal pour rire portrayed her next to Veuillot and the famous liberal Catholic, Comte de Montalembert, "who throw their most ardent wishes into the air in soap bubbles: auto-da-fe, Saint Barthélemy and the canonization of Rosette Tamisier." Linking Tamisier's "canonization" with brutal acts such as an auto-da-fe and the Protestant massacre of Saint Barthélemy (1572) placed the stigmatic within the "fanatical" branch of Catholicism with which the anticlerical activists attempted to associate her. ${ }^{85}$ Unlike in the satirical texts, Tamisier's figurative stigmata did not appear in the cartoons - perhaps because, as noted in the Punch song, they were covered (on her chest) and thus not always visible. Nevertheless, the wounds were implicit to her public persona, as it was the stigmata that had first given her the reputation for sanctity that the caricaturists now attacked.

In the case of Sor Patrocinio, because she was venerated as a "living saint" by the Spanish aristocracy, including the royal family, the anticlerical press used her image to create "the myth of the Throne against the people." ${ }^{\prime 6}$ She thus appeared in a great number of cartoons involving the royals and their clique, which denounced issues such as the interference of the Church in affairs of State, or the lucrative exploitation of mysticism and the stigmata. For example, a caricature of 1886 showed a nun in ecstasy with a small wound on her hand surrounded by clergymen and bags of money - an implicit reference to Sor Patrocinio, the one and only "nun with the wounds." 87 Another caricature of 1865 depicts Sor Patrocinio next to the "new Don Quixote," Father Claret, the royal court confessor. Their field is labelled as "neos" (neo-Catholics) and a train named "progress" approaches from behind (Figure 6.2).

Such politicized images of her also spread in the clandestine press, where cartoons circulated as cartes de visite and copied the pornographic style previously used to attack Marie-Antoinette and her clique, and which also became

84 Caricature by Honoré Daumier, published in Le Charivari, September 18, 1851, 3.

85 Caricature by Nadar (Gaspard-Félix Tournachon) in Le Journal pour rire, October 3, 1851, 1.

86 Jorge Vilches, "La propaganda republicana: la monarquía contra el pueblo. El caso de Isabel II (1854-1931)," Historia y Política 18 (2007): 231-253, 232. On anticlericalism in Spain, see especially Sanabria, Republicanism $15^{-3}$. About the satirical press in Spain, see Llera Ruiz, "Una historia."

87 See "Tribulaciones místicas," El Motín, September 19, 1886, 2. Apart from El Motín, most caricatures of Sor Patrocinio were published in journals such as Gil Blas, La Flaca and La Avispa. For more examples of cartoons involving the nun and the royal clique, see Graus, "Wonder nuns," 15-21. 
a common motif in anticlerical caricatures. ${ }^{88}$ One such cartoon represented Sor Patrocinio at an orgy in the palace showing Queen Isabel II a bloody piece of fabric. ${ }^{89}$ This refers to the well-known fact that the queen collected "relics" from the stigmatic and liked to wear her stained shirts ${ }^{90}$ - which was also mocked in foreign satirical journals such as the above-mentioned Punch. ${ }^{91}$

To our knowledge, apart from Rosette Tamisier and Sor Patrocinio, only Louise Lateau was caricaturized and mocked on a European scale during the period examined, which reaffirms the significance of these stigmatics becoming anticlerical targets during the nineteenth-century secular-Catholic conflicts. As Tine Van Osselaer has shown, Lateau had a symbolic meaning for both Catholics and anti-Catholics in the Belgian and German culture wars. Several caricatures of her appeared in Germany during the Kulturkampf, especially in the leading satirical journal, Kladderadatsch, which according to Wolfram Kaiser was accessible in public libraries. ${ }^{92}$ Her alleged wonders, such as the stigmata and inedia, were ridiculed, and Lateau was depicted as a false mystic and an ill woman. She was often paired with Paul Majunke, who, like Louis Veuillot in Tamisier's case, was depicted as a blind devotee and "manager."93

Michael O'Sullivan has recently analysed such depictions in the twentieth century, looking at how Therese Neumann, and the Konnersreuth circle in general, were attacked in the communist and the anticlerical social democratic press "to advocate for issues such as the separation of church and state and to embarrass Catholic political elites"94 - thus, with similar political intentions as in the nineteenth-century cases. Topics appearing in the caricatures and satirical texts of the above-mentioned stigmatics, such as the exploitation of stigmata and sanctity, or the mocking of inedia, also appeared in the case of

88 On Marie-Antoinette's pornographic caricature, see Hunt, "The many bodies." On the pornographic anticlerical caricatures, see e.g., Dixmier, Lalouette, Pasamonik, La République et l'Église, 94-98.

89 As scholars such as Isabel Burdiel have shown, in Spain, these images were part of a collection of watercolours called Los Borbones en pelota (c. 1868) ("The Bourbons in the buff"), produced by a collective of artists who signed with the pseudonym SEM or SEMEN. See Burdiel, "El descenso de los reyes," 9-10.

90 For references to Isabel II wearing the stained shirts see, for example, Morayta, Masonería española (1915), 175; Schiavo, Masonería española (1915), 366-367. On Isabel II's fascination for Sor Patrocinio see, Correspondencia de Pedro Egaña, Diversos Títulos Familias, 3557, Leg. 21, exp. 21, doc. 38, AHN.

91 "Saintly garment," Punch, January 30, 1869, 43.

92 Kaiser, "Clericalism," 70.

93 Van Osselaer, "Stigmata," 6o1-6o3.

94 O'Sullivan, Disruptive Power, 104. 
Neumann and the Konnersreuth circle. ${ }^{95}$ Thus, even in different times and national contexts, and facing distinct opponents of Catholicism, we find similarities in the anticlerical motifs used to denigrate stigmatics and their supporters.

In the cases of Neumann and Lateau, however, this was only one side of the story, as promotional images and texts were also circulating, and larger cults surrounded them. ${ }^{96}$ For Sor Patrocinio and Rosette Tamisier, on the contrary, it was the notion of fraud, as it appeared in daily newspapers, books or the anticlerical media during and after their trials, which nourished the image that survived them in the public sphere. This reputation eclipsed the stigmatics' own stories and, over time, continued to be mobilized in the anticlerical press to demystify other events involving stigmata and similar miracles. For example, in 1882, a Spanish stigmatized laywoman called Narcisa Navarro was compared to "the famous Sor Patrocinio who tricked the fools" in the anticlerical journal El Motin $;{ }^{97}$ and when, in 1886, some objects allegedly bled in Rouen, the journal Le Rappel, representative of the republican radicalisme, ironically claimed to be looking for "the Rosette Tamisier of the place" to debunk the miracle. ${ }^{98}$ Thus, the women came to incarnate a general notion of stigmatic fraud or related "bloody phenomena," where evoking their name was sufficient to advance the idea of deception.

\section{5}

Conclusions

Twenty years after the "Tamisier affair," a journalist recalled how, in the midst of the Bonapartist and Orleanist battles that had taken place at the end of the French Second Republic, a stigmatic had invaded the public debate: "Everyone still remembers Rosette Tamisier's epic story, her first triumphs, her trial and the final fiasco that crowned this Catholic speculation." 99 As we have seen, a similar thing had happened to Sor Patrocinio in Spain, with both women becoming the most remembered examples of modern stigmatic fraud in Europe.

95 For Neumann, O'Sullivan, Disruptive Power, 104-105.

96 See Chapter 5 as well as, e.g., Kane, "Stigmatic cults," 114-122; Van Osselaer, "Dor," 177-179.

97 "Manojo de flores místicas," El Motín 2.20 (1882), 1-2.

98 “M.M ...," Le Rappel, May 4, 1886, 4.

99 "Les miracles dans Vaucluse," La Revue artistique, November 1, 1872. "Chacun se souvient encore de l'épopée de Rosette Tamisier, de ses premier triomphes, de son procès et du fiasco final qui couronna cette spéculation catholique." 
Nevertheless, there have been attempts to restore the reputation of the Spanish stigmatic; firstly, when Queen Isabel II fostered her cause of beatification, opened in 1907, but still showing no sign of progression; ${ }^{100}$ and, secondly, even more recently, a Catholic scholar, Javier Paredes, has attempted to present the nun as the victim of the liberals with the aim of clearing her name and reigniting her cause. ${ }^{101}$ In the case of Rosette Tamisier, the historian of religion, Joachim Bouflet has questioned whether, despite having gone down in history as a "major mystifier (mystificatrice)," she was in fact an "authentic stigmatic" and "victim" of the conflict between the civil and ecclesiastical authorities. ${ }^{102}$

Without deciding whether there was any truth behind their stigmata, these two cases show how stigmatics could be perceived as political threats, and how accusations of "fake stigmata" and "self-styled sanctity" could be effective in neutralizing them. The idea that someone might generate the holy wounds to pass themselves off as a saint and obtain fame and power was not new; however, showcasing this idea by means of a mediatized trial and the anticlerical press was certainly a novelty in France and Spain. Ultimately, however, the target was not the stigmatic per se, but what she had come to represent in the public sphere. In this vein, looking at the secular repression of the stigmatics' public personae shows how they could become malleable religious celebrities, functioning not only to advance Catholic hopes, but also the agenda of the perceived political enemies of Catholicism. In the following chapter, we will see how the holy wounds and their bearers were received by the highest Roman Catholic authority, the Vatican.

\footnotetext{
100 Statement by Queen Isabel II, 18 January 1904, Procesos de Beatificación, Causa de Beatificación de Sor Patrocinio (1907), Fol. 659-684, ADT.

101 See Paredes, Las llagas de la monja, and also Paredes, Vida admirable.

102 Bouflet in Imbert-Gourbeyre, La stigmatisation, ed. Joachim Bouflet, 484.
} 


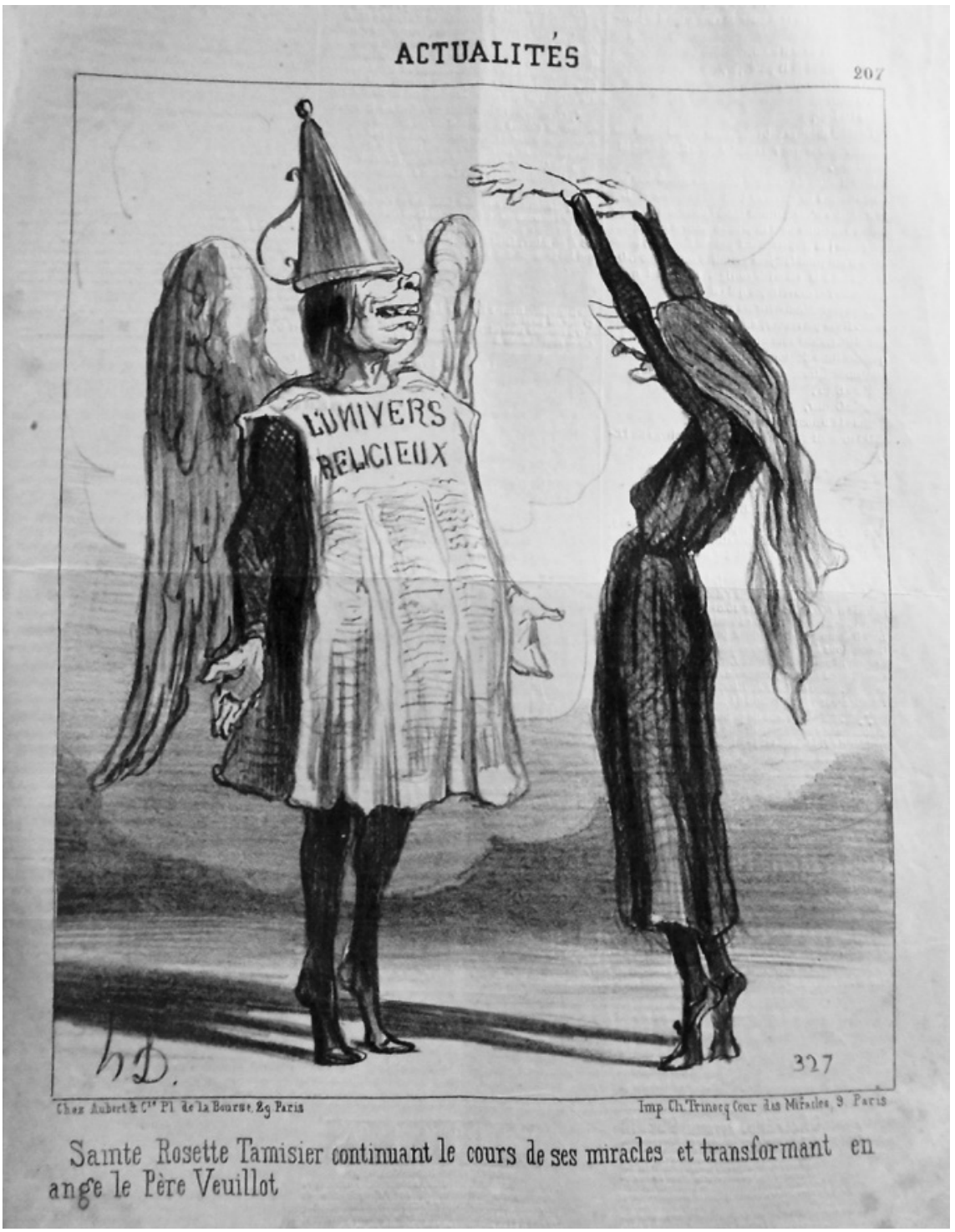

FIGURE 6.1 "Saint Rosette Tamisier continuing with her miracles and transforming Father Veuillot into an angel." Caricature by Honoré Daumier published in: Le Charivari, 20.261 (18 September 1851): 3

BIBLIOTHÈQUE NATIONALE DE FRANCE 


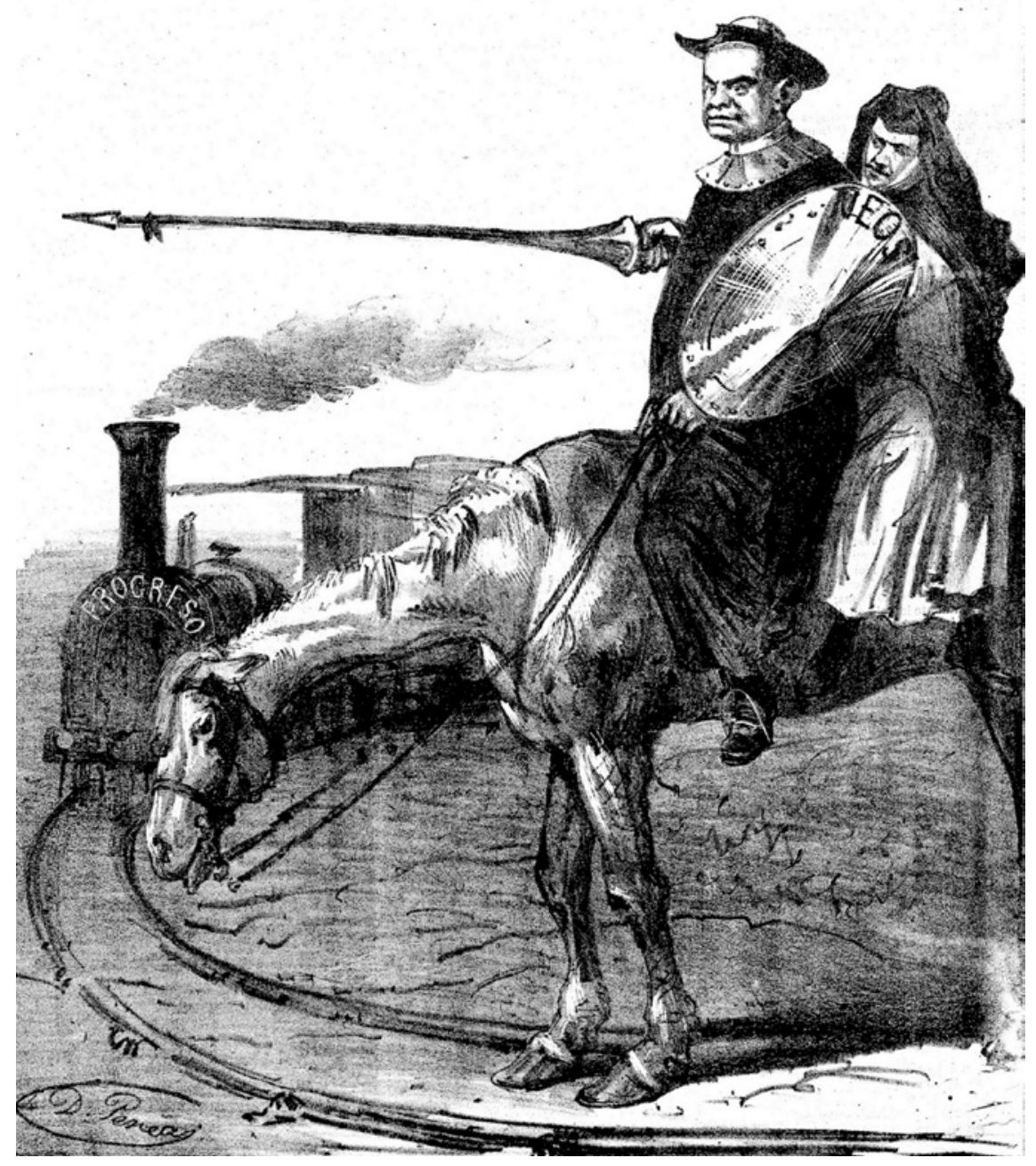

FIGURE 6.2 "The new Don Quixote." Published in: Gil Blas, 2.40 (2 September 1865): 3 BIBLIOTECA NACIONAL DE ESPAÑA 